\title{
Application of a binary logistic model in the development of strategies to encourage sustainable transportation in medium-sized cities: case of study
} \author{
Paulo César Emiliano ${ }^{4}$ \\ ${ }^{1}$ Federal University of Viçosa, Minas Gerais, Brazil, natalia.brasil@ufob.edu.br \\ 2Federal University of Viçosa, Minas Gerais, Brazil, heraldo.pitanga@ufv.br \\ ${ }^{3}$ Federal University of Viçosa, Minas Gerais, Brazil, taciano.silva@ufv.br \\ ${ }^{4}$ Federal University of Viçosa, Minas Gerais, Brazil, paulo.emiliano@ufv.br
}

Natalia Assunção Brasil Silva ${ }^{1}$, Heraldo Nunes Pitanga ${ }^{2}$, Taciano Oliveira da Silva ${ }^{3}$,

\section{Recebido:}

25 de junho de 2019

Aceito para publicação:

6 de março de 2020

Publicado:

31 de agosto de 2020

Editor de área:

Sara Ferreira

\section{Keywords:}

Sustainable urban mobility. Motorized and non-motorized modes of transportation.

Logistic regression model.

\section{Palavras-chaves:}

Mobilidade urbana sustentável.

Meios de transporte motorizados e não motorizados.

Modelo de regressão logística.

DOI:10.14295/transportes.v28i3.2100

\begin{abstract}
Demographically medium-sized cities play a significant role in the economy and population spreading in growing countries. Their development and fast pace expansion reveal the need for an efficient, sustainable mobility plan. Once the transport mode used by the population affects the sustainability of urban trips, it is crucial to understand the influence that socioeconomic and daily trips characteristics exert on the choice of transportation modes. In this context, having as study scenery, the reality of Barreiras, a demographically medium-sized city located in Bahia State, this paper aims to identify and quantify the impact of those characteristics in the usage of transportation by the corresponding population and, consequently, its effects in sustainable mobility. To do that, we exploited the association strength of inherent society characteristics with the choice of transportation mode, measured through a predictive binary logistic regression model. We concluded that statistical modeling of variables that are inherent to investigated medium-sized city population could assist the design of strategies to encourage the use of sustainable transportation modes.
\end{abstract}

\section{RESUMO}

O protagonismo das cidades de médio porte demográfico na economia e na dispersão populacional dos países em crescimento gera o desenvolvimento e a expansão acelerada destas cidades, evidenciando a necessidade de um eficiente planejamento de mobilidade sustentável. Como a sustentabilidade está baseada nos transportes, é importante compreender a influência que as características socioeconômicas e de deslocamentos diários exercem na forma de utilização dos transportes. Para identificar e quantificar o impacto dessas características na utilização dos transportes, este artigo propõe um método de auxílio à promoção da sustentabilidade no planejamento da mobilidade dessas cidades, baseado na força de associação das características inerentes à sociedade com a escolha do meio de transporte e no modelo de regressão logística. Através da aplicação do método, concluiu-se que a modelagem estatística das variáveis inerentes à população das cidades de médio porte demográfico pode auxiliar na elaboração de políticas públicas sustentáveis na área de mobilidade.

\section{INTRODUCTION}

\subsection{Problem contextualization}

Demographically medium-sized cities in Brazilian territory have a prominent position on economic development, on ongoing regional dispersal, and on spreading modern activities of the country (Stamm et al., 2013). However, as in populous cities, the medium-sized cities also have growing social, economic, and environmental problems, due to dependency upon personal 
motorized transportation (automobile). The size of those problems highlights the urgency of Sustainable Urban Mobility Plans (SUMP) in such cities so that difficulties regarding mobility do not become hard to be solved, as it happens in metropoles.

As for the SUMP, it is worth highlighting that the insertion of the word sustainability arose as a new paradigm in the world of transportation policy (López and Montero, 2018). Mobility, previously defined as freedom of choice in determining the mode of transportation that pleases the need of an individual, began to encompass movement safety, human health, and environment preservation (Silva et al., 2015). Based on that new approach, SUMP focuses on the needs of people and options of more sustainable transportation, as opposed to traditional approaches that were centered on motorized roadway traffic and on providing infrastructure.

Upon that new paradigm, European countries, such as France, United Kingdom, Italy and Germany, use SUMP strategies to mitigate adverse impacts of motorized modes of transportation and to reduce dependency of automobile, and also provide financial and technical supports to those strategies (Diez et al., 2018; Machado and Picinini, 2018). In this context, Brazil has promulgated its National Policy of Urban Mobility (NPUM) (Law 12.587) in 2012, with guidelines that stimulate the prioritization of non-motorized modes of transportation over the motorized ones and place public transportation system over motorized single-occupant vehicles.

Since SUMP strategies or guidelines of different countries are focused on the use of transportation, planners should be aware of the fact that the choice of the transportation mode is related to the heterogenicity of the socioeconomic and spatial context of the individuals. In other words, the choice of transportation mode is not the same considering people with different incomes, frequency, and reason for the trip, among other issues (Páez, 2006; Portugal, 2017). For this reason, Xu et al. (2018) consider indispensable to study the socioeconomic and trip characteristics during SUMP, to assist the design of the public policy.

Due to the complexity of these issues regarding urban mobility patterns, several authors appeal to linear statistical models, generalized linear, semi-linear and nonlinear models (Moons et al., 2007), to understand the influence of different variables in using the transportation mode and in determining the demand for transports in its modal division step (Coutinho et al., 2015). Based on the search for sustainable mobility, highlighted by Cardoso and Campos (2016), and considering the relative success shown by statistic modeling in studies related to transportation modes, statistical modelling of society inherent characteristics that influence the choice of the transportation mode can help the development of strategies to encourage the use of sustainable transport modes.

Application of modeling in studies aiming the comprehension of population behavior regarding the use of transportation modes to stimulate sustainable urban mobility remains, however, limited. Therefore, considering the contextualization of the problem, this research proposes to identify and quantify, upon analysis of a binary logistic regression model, the impact of social, economic, and trip characteristics in the choice of the transportation mode and, consequently, its effects in sustainable mobility. The object of this investigation was the urban area population of Barreiras city, in Bahia State, which fits in the demographically medium-sized city class, according to the classification presented by IBGE (2010) and Stamm et al. (2013). 


\section{THEORETICAL REFERENCE}

Due to the temporal evolution of transportation modes, there are different definitions of system sustainability. However, it is broadly accepted that the sustainable transportation system indicates balancing environmental, social, and economic developments of the present with the ones of the future (Contursi et al., 2018). The reality, however, exposes the unsustainability of the current system, upon the comparison between this definition and the resulting problems from urban trips, such as traffic congestion, traffic accidents, and consumption of finite resources (petroleum) (Mingzhu et al., 2013). For that reason, Contursi et al. (2018) point out a growing and generalized investigation of ways to better understand and plan urban environment, in order to enable more sustainable mobility patterns which, according to Machado and Picinini (2018), encompass transportation system and non-motorized modes.

López and Montero (2018) stated that public investments should be driven to sustainable transportation modes, in other words, massive (collective) and non-motorized (cycling and walking), oriented to the qualitative dimensions of transportation, travel quality and social equity issues and citizen representation in transportation. However, according to Mello et al. (2016) and Portugal (2017), a sustainable mobility plan is beyond transport activity itself, for it also spans the association of social, economic, and trip patterns characteristics with categories of lower social and environmental impact. Different researchers covered some variables of those characteristics in studies about the use of transportation modes, as shown in Table 1.

Table 1 - Researches related to variables of social, economic, and trip patterns characteristics

\begin{tabular}{|c|c|c|}
\hline Characteristics & Variables & References \\
\hline \multirow{3}{*}{ Social } & Age & $\begin{array}{l}\text { Horn, 1993; Arora and Tiwari, 2007; Rahul and Verma, 2013; } \\
\text { Tyrinopoulos and Antoniou, 2013; CNT, } 2017 .\end{array}$ \\
\hline & Gender & $\begin{array}{l}\text { Horn, 1993; Arora and Tiwari, 2007; Rahul and Verma, 2013; CNT, } \\
\text { 2017; Gadepalli et al., } 2018 .\end{array}$ \\
\hline & Education background & Horn, 1993; Arora and Tiwari, 2007; Carse et al., 2013. \\
\hline \multirow{4}{*}{ Economic } & $\begin{array}{l}\text { Monthly income } \\
\text { (family or individual) }\end{array}$ & $\begin{array}{l}\text { Horn, 1993; Gomide, 2006; Arora and Tiwari, 2007; Lindner and } \\
\text { Pitombo, 2016; CNT, 2017; Gadepalli et al., } 2018 .\end{array}$ \\
\hline & $\begin{array}{l}\text { Domestic comfort } \\
\text { (appliances) }\end{array}$ & Ferrante et al., 1997; ABEP, 2016. \\
\hline & $\begin{array}{l}\text { Housing characteristics } \\
\text { (rented or owned) }\end{array}$ & Ferrante et al., 1997. \\
\hline & Ownership of motorized vehicle & $\begin{array}{l}\text { Rahul and Verma, 2013; Carse et al., 2013; Lindner and Pitombo, } \\
\text { 2016; CNT, } 2017 .\end{array}$ \\
\hline \multirow{4}{*}{$\begin{array}{l}\text { Trip } \\
\text { pattern }\end{array}$} & Average time of travel & $\begin{array}{l}\text { Rahul and Verma, 2013; Vale, 2013; CNT, 2017; Garcia et al., 2018; } \\
\text { Gadepalli et al., } 2018 .\end{array}$ \\
\hline & Travel distance & Carse et al., 2013; Garcia et al., 2018. \\
\hline & Travel purpose & Carse et al., 2013; CNT, 2017; Xu et al., 2018. \\
\hline & Habit of using motorized vehicle & Kaewkluengklom et al., 2017. \\
\hline
\end{tabular}

Based on the researches shown in Table 1, it is possible to verify several variables influencing the choice of transport modes, which reinforces the need to consider them in SUMP through efficient methods that can identify and promote the comprehension of the predictive factors of sustainable transportation usage. Researchers and planners, such as the ones shown in Table 2, use logistic models to understand the influence of some features in choosing the transportation mode. 
Based on the results achieved by the abovementioned researches, it is possible to realize the effectiveness of the logistic regression models in understanding and determining predictor factors of transport mode choice. Therefore, the binary logistic regression model can work as a tool to assist the fostering of sustainability in urban mobility plans, through the estimation of population behavior in choosing sustainable transport modes. With that in mind, statistical analysis can help public policy planners to understand the behavior of users in a coherent way, taking into account the different characteristics that permeate the urban environment, helping to better understand the needs of the users and, thus, enabling proposition of measures that make the motorized transport mode users to become non-motorized users and commuters, as well as keep those who already use them.

Table 2 - Studies that used logistic models to understand the choice of transportation mode

\begin{tabular}{|c|c|c|}
\hline References & Objectives & Results \\
\hline Rahul and Verma (2013) & $\begin{array}{l}\text { Determining the impact of social and } \\
\text { environmental characteristics on choosing } \\
\text { non-motorized modes, walking, cycling, in } \\
\text { Bangalore, India. }\end{array}$ & $\begin{array}{l}\text { - Increase in age and travel time reduces the } \\
\text { probability of a person to walk and use a bike; } \\
\text { - People who own at least one motorized vehicle } \\
\text { have a lower probability of using non-motorized } \\
\text { modes when compared to people who do not } \\
\text { own a motorized vehicle; } \\
\text { - Women tend to walk more than men. }\end{array}$ \\
\hline Carse et al. (2013) & $\begin{array}{l}\text { Analyzing the predictors of car usage in } \\
\text { comparison to bicycles in Cambridge, United } \\
\text { Kingdom. }\end{array}$ & $\begin{array}{l}\text { - Travel distance and free parking on the } \\
\text { worksite were strongly associated with the use } \\
\text { of a car for work trips; } \\
\text { - The availability of cars and lower levels of } \\
\text { education were associated with the use of cars } \\
\text { for leisure and shopping trips, and shorter } \\
\text { distance trips. }\end{array}$ \\
\hline Vale (2013) & $\begin{array}{l}\text { Identifying explanatory variables and their } \\
\text { effect on people's behavior regarding trips in } \\
\text { Lisbon, Portugal. }\end{array}$ & $\begin{array}{l}\text { - Car use is higher when travel time increases; } \\
\text { - There is transportation mode inertia within the } \\
\text { acceptable travel time. }\end{array}$ \\
\hline $\begin{array}{l}\text { Lindner and Pitombo } \\
\text { (2016) }\end{array}$ & $\begin{array}{l}\text { Relating the use of single-occupant motorized } \\
\text { transport and commuting with domicile } \\
\text { socioeconomic variables (number of people in } \\
\text { domicile, family income, number of vehicles } \\
\text { and motorcycles in domicile), travel variables } \\
\text { (total travel distance run in domicile) in São } \\
\text { Paulo metropolitan region, Brazil. }\end{array}$ & $\begin{array}{l}\text { - Lower income increases the probability of } \\
\text { commuting; } \\
\text { - The number of cars in domicile and the total } \\
\text { number of trips have an inverse correlation with } \\
\text { the choice of public transportation. }\end{array}$ \\
\hline $\begin{array}{l}\text { Kaewkluengklom et al. } \\
\text { (2017) }\end{array}$ & $\begin{array}{l}\text { Verifying the influence of psychological } \\
\text { features on choosing the use of Bus Rapid } \\
\text { Transit (BRT) in Khonkaen, Thailand. }\end{array}$ & $\begin{array}{l}\text { - People who habitually use private vehicles } \\
\text { show lower intention of using BRT. }\end{array}$ \\
\hline Gadepalli et al. (2018) & $\begin{array}{l}\text { Presenting a methodology to understand the } \\
\text { breadth of socioeconomic features in } \\
\text { commuting trips demands in Visakhapatnam, } \\
\text { India. }\end{array}$ & $\begin{array}{l}\text { - Gender, income, and travel time influence } \\
\text { transport mode choice; } \\
\text { - Waiting time has a stronger effect on transport } \\
\text { mode choice. }\end{array}$ \\
\hline
\end{tabular}

\section{ADOPTED METHODOLOGY}

No studies are establishing a methodological process to understand the profile of sustainable transport users in medium-sized cities up to this moment. This paper aims to fill in this gap, in which the proposed process is based on sampling and analyzing social, economic and population trip patterns characteristics, as shown in Figure 1. 


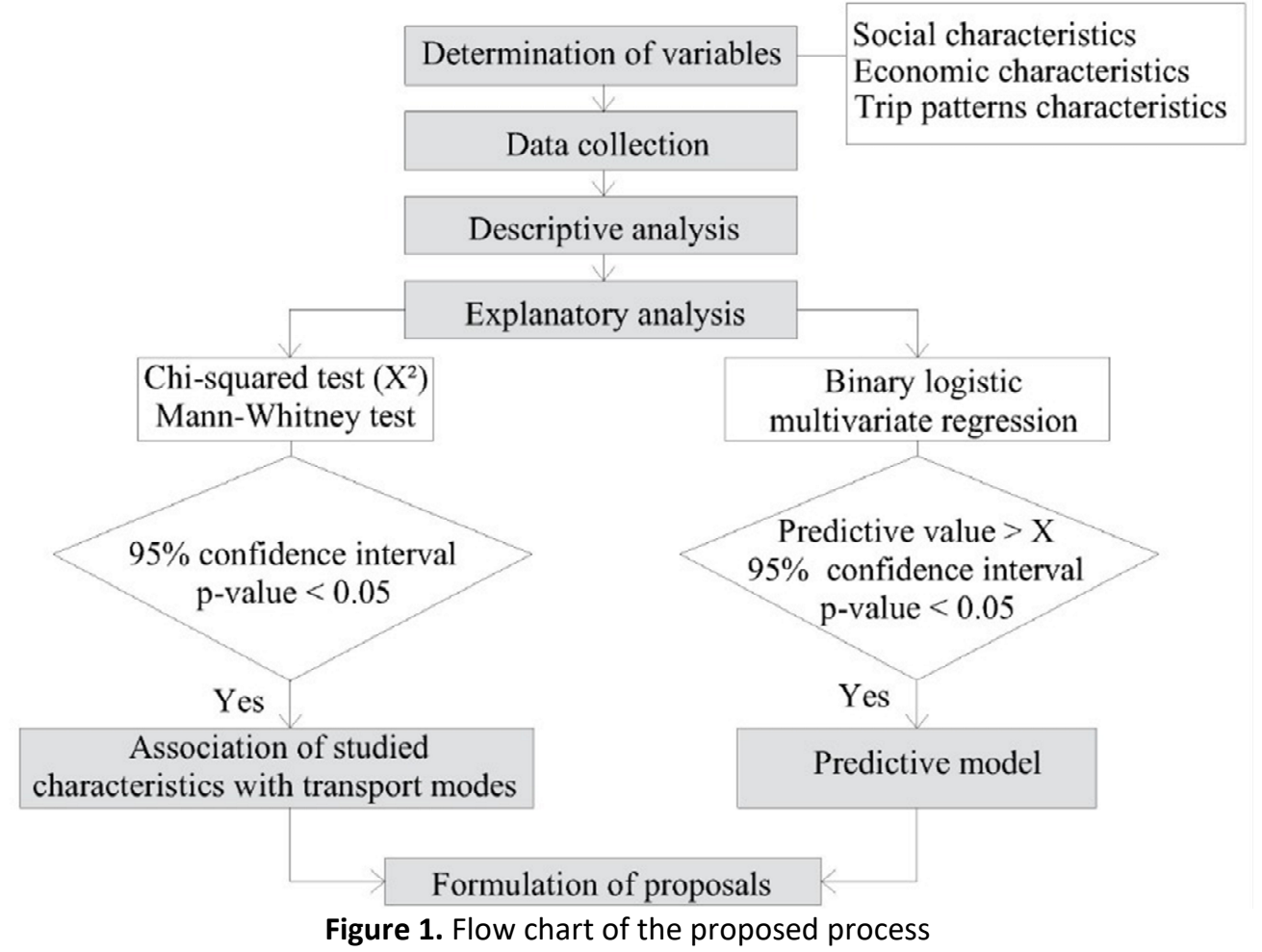

\subsection{Exploratory survey}

Sampled data (exploratory survey) can be obtained by applying online surveys. To do that, though, the respondent must have an internet connection. That is dispensable if the sampling is done through interviews, either on-site or by telephone. Upon the online approach, the survey becomes quicker at data collection. That is because most well-established data collection methods have limitations, such as application time, financial, and geographical restrictions, while the use of the internet is growing as a resource to publish information.

Based on the approach done in other studies, such as the ones shown in Table 1, the survey must include information related to gender, skin color, age, education background, monthly family income, housing characteristics, domestic comfort, ownership of motorized vehicle, transportation mode, purpose of trip, average frequency of daily trips and average travel time. In order to determine the simple random sampling in the exploratory survey, equation 1 is used (Triola, 2013).

$$
\mathrm{n}=\frac{\mathrm{Np}(1-\mathrm{p})\left(\mathrm{z}_{\alpha / 2}\right)^{2}}{(\mathrm{~N}-1) \varepsilon^{2}+\left(\mathrm{z}_{\alpha / 2}\right)^{2} \mathrm{p}(1-\mathrm{p})}
$$

In which: $\mathrm{n}$ : minimum size of the sample in the survey;

$\mathrm{N}$ : estimated size of the population in the year of the study;

$\varepsilon$ : $\quad$ sampling error;

$z_{\alpha / 2} \quad$ standardized normal variable associated with a certain level of confidence $\alpha$, such that $p(Z<z)=1-\alpha / 2$

p: $\quad$ populational proportion. 


\subsection{Analysis}

\subsubsection{Descriptive analysis}

In order to characterize the sample and draw users' profiles regarding transport modes used in the urban area, it is necessary to carry out a descriptive analysis of sampled data, in which characteristics with quantitative variables are described by mean and standard deviation, while qualitative variables are described by percentages.

\subsubsection{Explanatory analysis}

Association between each studied variable with the dependent variable (transport mode choice) is made in the first explanatory analysis, from statistic tests, chi-squared test $\left(\chi^{2}\right)$, for categoric or qualitative variables, and Student's T-test or Mann-Whitney test, when appropriate, for quantitative or continuum-type variables. For statistical significance, a 95\% confidence interval (CI95\%) and a p-value $<0.05$ are adopted. However, many researchers sustain a combined analysis of $p$-value with effect size, because they consider that p-value is just a quantitative variable, while the effect size represents the effect of association or correlation between the variables to be analyzed (Ferreira and Patino, 2015).

For that reason, when calculating the effect size, in other words, the magnitude understood as correlation of strength of association of the characteristics used in the survey with the transport modes (non-motorized and collective motorized versus personal motorized), Cohen $d$ test for continuum variables was used, with the following interpretation classification: 0.20-0.49, small; 0.50-0.79, medium; and equal or higher than 0.80, large (Cohen, 1992). Cramer $V$ was used for categoric variables, as a measure of effect magnitude to test the differences between proportions, and the following classification for interpretation was adopted: $0.10-0.29$, small; 0.30-0.49, medium; and equal or higher than 0.50, large (Cohen, 1992).

Besides, Binary Logistic Multivariate Regression analysis was used to estimate the probability of occurrence of a citizen use non-motorized or motorized collective transport mode. This model is based on the forward stepwise method, by maximum likelihood criteria, or Likelihood Ratio (LR), which adds the variables based on significance verified in statistical scores and removes them from the tests according to the maximum likelihood statistic. According to Corrar et al. (2009), evaluation of adjustment of logistic model is carried out by Likelihood Value (-2LL), Nagelkerke pseudo R2, and by Hommer and Lemeshow test, and statistical significance of every coefficient is analyzed based on the Wald test.

In order to perform the proposed statistical modeling, explanatory variables were coded in dummy binary variables $(0 / 1)$, in which value 1 was assigned to characteristics associated with users of non-motorized and collective motorized transportation modes.

Statistical analyses allowed to establish the profile of users of non-motorized and collective motorized transportation modes, and their transport mode choice behavior, according to the reality of the urban area of each medium-sized city.

\section{LOCATION OF METHODOLOGY APPLICATION}

Barreiras, with an estimated population of 153,831 inhabitants, the most populous city of western Bahia State, Northeast region of Brazil IBGE, 2018), was the chosen place to perform the adopted methodology in this research (Figure 2). 
The city is an important road junction among North, Northeast and Center-West regions of Brazil, likely tending to expansion due to its economic potential. In addition, Barreiras is among the fifteen biggest grain producers in Brazil (SEI, 2017), and therefore plays a vital role in Brazilian agribusiness and, consequently, in the national economy. In ten years (2008 to 2018), the city increased its motorized vehicles fleet by $255 \%$, in which touring vehicles and motorcycles accounted for $250 \%$ and $270 \%$, respectively (DENATRAN, 2018).
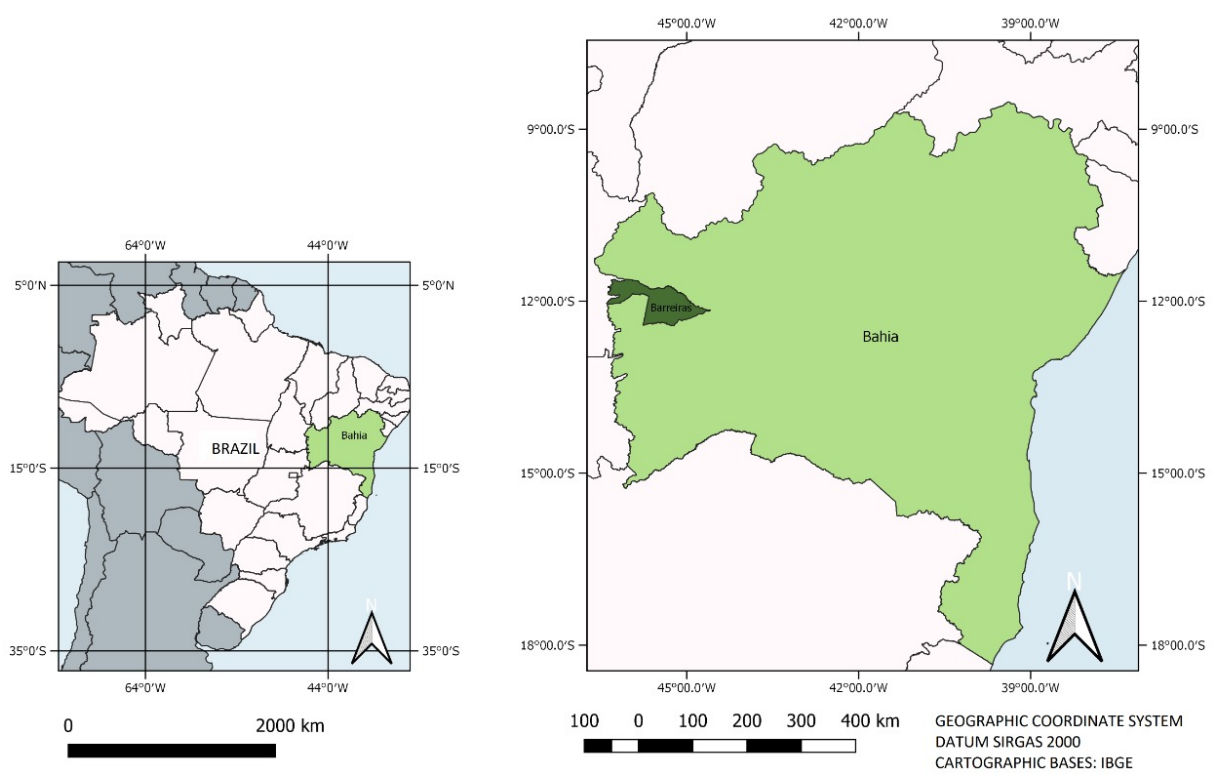

Figure 2. Barreiras location within Bahia State and in Brazil

With the purpose of collecting data about the socioeconomic profile and trip pattern, an online form for exploratory survey was provided from July $10^{\text {th }}$ to August $20^{\text {th }}, 2018$. In order to calculate the minimum significative sample, equation 1 was considered, in which: $\mathrm{N}$ was the estimated size of Barreiras' population in 2018. Sampling error $\varepsilon$ was 6\%; standardized normal variable, $\mathrm{z}_{\alpha / 2}$, associated with a $95 \%$ confidence level, was 1.96; and the estimated populational proportion $\mathrm{p}$ adopted was $50 \%$. Therefore, the estimated minimum sample of respondents was 267 individuals.

On the Binary Logistic Multivariate Regression model, a 40\% cutoff threshold was considered to classify the individual as a user of non-motorized and collective motorized transport mode. In other words, when replacing the values of the predictive variables on the model, if the predicted value for that individual is higher than $40 \%$, it is classified as a user of non-motorized and collective motorized transport mode. Otherwise, it is classified as a user of personal motorized transport mode. The odds ratio (OR) and a 95\% confidence interval (CI95\%) were calculated, with a $5 \%$ significance level. All statistical analyses were performed with IBM SPSS software, version 20.0 .

\section{RESULTS AND ANALYSIS}

The sample population comprised 314 individuals, of which 24 use bicycles, 15 are walkers, 78 use buses, 27 use motorcycle, and 170 use a private vehicle as primary travel mode. As for the main transport mode, $37.3 \%(n=117)$ of respondents are walkers or use a bicycle or collective motorized vehicle (bus), which became Group 1 of this research. The other $62.7 \%(n=197)$ 
respondents who use mainly motorcycle or private vehicle formed Group 2 . Table 3 presents general characteristics obtained by the online survey and the correlation or effect between them and the transport modes.

Table 3 - Descriptive analysis of the urban area sample in Barreiras city, Bahia

\begin{tabular}{|c|c|c|c|c|c|c|c|}
\hline Variables & tratification & Group 1 & Group 2 & $\mathbf{n}$ & $\%$ & p-Value & Effect Size \\
\hline \multirow[t]{3}{*}{ Gender } & Women & $58 \%$ & $48 \%$ & 163 & $52 \%$ & 0.09 & - \\
\hline & Men & $42 \%$ & $52 \%$ & 151 & $48 \%$ & & \\
\hline & White & $24 \%$ & $45 \%$ & 116 & $37 \%$ & $<0.001^{*}$ & $0.23^{(5)}$ \\
\hline \multirow[t]{2}{*}{ Skin color } & Brown & $53 \%$ & $45 \%$ & 150 & $48 \%$ & & \\
\hline & Black & $23 \%$ & $10 \%$ & 48 & $15 \%$ & & \\
\hline \multirow[t]{3}{*}{ Age (years) } & & $26.3 \pm 10.0$ & $33.4 \pm 9.6$ & $30.8=$ & \pm 10.3 & $<0.001 *$ & - \\
\hline & Reads and writes & $1 \%$ & $0 \%$ & 1 & $1 \%$ & $<0.001^{*}$ & $0.35^{(5)}$ \\
\hline & Middle School & $4 \%$ & $1 \%$ & 7 & $2 \%$ & & \\
\hline \multirow[t]{4}{*}{ Educational background } & High School & $5 \%$ & $4 \%$ & 13 & $4 \%$ & & \\
\hline & Graduation & $71 \%$ & $41 \%$ & 164 & $52 \%$ & & \\
\hline & Post-Graduation (1) & $19 \%$ & $54 \%$ & 129 & $41 \%$ & & \\
\hline & 1 to 3 minimum wages & $50 \%$ & $12 \%$ & 82 & $26 \%$ & $<0.001^{*}$ & $0.41^{(4)}$ \\
\hline \multirow{3}{*}{ Monthly family income (2) } & 3 to 6 minimum wages & $27 \%$ & $20 \%$ & 72 & $23 \%$ & & \\
\hline & 6 to 10 minimum wages & $15 \%$ & $31 \%$ & 78 & $25 \%$ & & \\
\hline & Above 10 minimum wages & $8 \%$ & $37 \%$ & 82 & $26 \%$ & & \\
\hline \multirow{2}{*}{ Housing (owned) } & Yes & $51 \%$ & $70 \%$ & 197 & $63 \%$ & $0.001^{*}$ & $0.18^{(5)}$ \\
\hline & No & $49 \%$ & $30 \%$ & 117 & $37 \%$ & & \\
\hline \multirow{2}{*}{ Domestic comfort ${ }^{(3)}$} & Yes & $63 \%$ & $91 \%$ & 253 & $81 \%$ & $<0.001^{*}$ & $0.34^{(4)}$ \\
\hline & No & $37 \%$ & $9 \%$ & 61 & $19 \%$ & & \\
\hline \multirow{4}{*}{ Owned motorized vehicle } & Yes & $17 \%$ & $93 \%$ & 204 & $65 \%$ & - & - \\
\hline & No & $83 \%$ & $7 \%$ & 110 & $35 \%$ & & \\
\hline & Work & $30 \%$ & $74 \%$ & 181 & $58 \%$ & $<0.001^{*}$ & $0.42^{(5)}$ \\
\hline & Education & $60 \%$ & $19 \%$ & 109 & $34 \%$ & & \\
\hline \multirow[t]{3}{*}{ Purpose of trip } & Shopping & $7 \%$ & $4 \%$ & 15 & $5 \%$ & & \\
\hline & Leisure & $2 \%$ & $3 \%$ & 7 & $2 \%$ & & \\
\hline & Health & $1 \%$ & $1 \%$ & 2 & $1 \%$ & & \\
\hline $\begin{array}{l}\text { Average frequency of daily } \\
\text { trips }\end{array}$ & & $2.0(2.0)$ & $4.0(2.0)$ & - & - & $<0.001^{*}$ & - \\
\hline Average time of travel & & $20.0(15.0)$ & $12.0(8.0)$ & - & - & $<0.001^{*}$ & - \\
\hline \multicolumn{8}{|c|}{$\begin{array}{l}\text { (1) Post-graduation comprised specialization, master, and doctorate } \\
\text { (2) Minimum wage: unified monthly amount, defined by law in Braz } \\
\text { of their own and their family (BRASIL, 1988); } \\
\text { (3) A house with domestic comfort has more than four appliances. } \\
\text { (4) Cohen's } d \text {. } \\
{ }^{(5)} \text { Cramer's V. } \\
\text { *Significative differences }(p<0.05) \text {. }\end{array}$} \\
\hline
\end{tabular}

Based on the descriptive analysis, most of the interviewed had monthly family income above three minimum wages, owned house and a motorized vehicle had domestic comfort, and more than four appliances at home. With this result, one can deduce that the data collection method, based on the online survey, did not cover many people who have a less educational background and lower income, due to their lower frequency of internet access (IBGE, 2016). However, such limitation does not interfere in the proposed method, considering that its application aims to understand the user's profiles of sustainable transport modes in medium-sized cities.

Within the stratifications of the education background variable, there was greater participation of graduated individuals, for users of transports of Group 1, and post-graduated and graduated individuals, for users of the Group 2. It is worth highlighting that online surveys reach mostly people of higher educational background, due to their more straightforward access to the internet. 
In a general analysis of the studied variables, percentages of brown or black women that use transports of Group 1 are higher, when compared to the percentages of men and white skin color, respectively. People with a higher educational background, especially with postgraduation, use transports of Group 2 more. Use of transports of Group 1 decreases as user monthly family income rises. The use of transports of Group 2 is higher among people who own a house and have domestic comfort and a car. According to these results, a higher number of trips correlates with work and education activities. As for work trips, most of the interviewed use transports of Group 2, while for education purposes trips, transports of Group 1 are more used. Concerning the characteristics of the trips, a higher percentage of the interviewed makes, in average, more than three trips a day, with a 15 minutes average time of travel, and the purposes are in the following decreasing order: work, education, shopping, leisure, and health, respectively.

Users from Group 1 and Group 2 are not statistically different concerning gender (p-value > 0.05). In other words, statistically, the individual's gender does not interfere in transport mode choice. However, both significative and moderate magnitude differences were found regarding age, education background, and purpose of the trip.

As for skin color, monthly family income, housing characteristics, domestic comfort, the average frequency of daily trips, and average time of travel, both user groups showed a significative difference, which, nonetheless, have small magnitude effect, according to Cohen's $d$ test and Cramer's $V$ test. In the face of the magnitude analysis of association strength between transport modes and variables, it is concluded that age, educational background, and purpose of the trip show more considerable influence regarding transport choice when compared to the remaining characteristics considered statistically significative

(p-value $\leq 0.05)$.

Based on the socioeconomic variables showing significative difference between the analyzed groups, and the responses obtained in this survey, it can be inferred that the users' profile of non-motorized, and collective motorized (bus) transport modes comprises people who are younger, have brown and black skin color, with a monthly family income below three minimum wages, live in rented domiciles with up to four appliances, and make less trips which last longer, with the primary purpose of education.

Table 4 - Binary logistic model to calculate the probability of using non-motorized and collective motorized (bus) transport modes by analyzed users' groups

\begin{tabular}{|c|c|c|c|c|}
\hline Variable & Coefficient & Parameter Estimative & p-value & Odds Ratio (Cl95\%) \\
\hline Intercept & $\beta_{0}$ & -3.347 & $<0.0001$ & 0.035 \\
\hline $\begin{array}{l}\text { Monthly Family income } \\
\text { (less than } 3 \text { minimum wages) }\end{array}$ & $\beta_{1}$ & 1.216 & 0.001 & $3.37(1.64-6.93)$ \\
\hline $\begin{array}{l}\text { Education background } \\
\text { (Below or equal to graduation) }\end{array}$ & $\beta_{2}$ & 0.762 & 0.04 & $2.14(1.04-4.44)$ \\
\hline Housing characteristic (Rented) & $\beta_{3}$ & 0.861 & 0.007 & $2.37(1.27-4.40)$ \\
\hline Purpose of trip (Education) & $\beta_{4}$ & 0.940 & 0.004 & $2.56(1.35-4.86)$ \\
\hline $\begin{array}{l}\text { Average frequency of daily trips } \\
\text { (Less or equal to } 3 \text { trips) }\end{array}$ & $\beta_{5}$ & 1.552 & $<0.0001$ & $4.72(2.58-8.64)$ \\
\hline Average time of travel (Above 15 minutes) & $\beta_{6}$ & 1.119 & $<0.0001$ & $3.06(1.66-5.63)$ \\
\hline
\end{tabular}


Table 4 shows the logistic regression coefficients and their significance on the determination model of sustainable mobility (equation 2), concerning the non-motorized and collective motorized (bus) transport modes. The model explains approximately 50\% of the variation in the transport mode choice of the analyzed users' groups. The statistically significant variables were monthly family income, educational background, housing characteristics, the purpose of the trip, the average frequency of daily trips, and the average time of travel.

The determination model of sustainable mobility is based on equation 2 .

$$
P(\%)=100^{*} \frac{1}{\left(1+\exp \left(-\left(-3.347+1.216 \mathrm{X}_{1}+0.762 \mathrm{X}_{2}+0.861 \mathrm{X}_{3}+0.940 \mathrm{X}_{4}+1.552 \mathrm{X}_{5}+1.119 \mathrm{X}_{6}\right)\right)\right)}
$$

In which: $P$ : probability, in a specified category, of an individual to use a non-motorized and collective motorized (bus) transport mode, with fixed levels of the remaining categories;

$\mathrm{X}_{\mathrm{i}}$ : model-independent variables, according to the coefficient index (i), of Table 4.

The model presented in equation 2 showed $80.3 \%$ accuracy in the classification of the type of transport mode used by the interviewed in this research. The sensitivity [right adjustment of individuals who use non-motorized and collective motorized (bus) transport modes was 76.1\%, and specificity [right adjustment of individuals who use motorized and personal (car/motorcycle) transport modes] was $82.7 \%$, according to Table 5.

Table $\mathbf{5}$ - Classification of the transport mode used by the groups of transport modes users analyzed by the logistic regression model

\begin{tabular}{lccc}
\hline \multicolumn{3}{c}{ Estimated } \\
\hline Observed & Personal motorized (car/motorcycle) & $\begin{array}{c}\text { Non-motorized and Collective } \\
\text { motorized (bus) }\end{array}$ & Hit percentage \\
\hline Personal motorized & 163 & 34 & $82.7 \%$ \\
\hline $\begin{array}{l}\text { Non-motorized/ } \\
\text { Collective motorized }\end{array}$ & 28 & 89 & $76.1 \%$ \\
\hline Total & & & $80.3 \%$ \\
\hline
\end{tabular}

Based on the forward stepwise method used in this research, it is concluded that the presented method is what best predicts the possibility of using non-motorized and collective motorized (bus) transport modes, for this study. Since only variables considered statistically significant are present on the model, namely, the variables that influence in transport mode choice, one can deduce, based on the selected explanatory variables, that it is not possible to reject the null hypothesis which, on the model, variables do not affect the determination of transport mode usage by the population of the study area.

Interpretation of the reported variables allows us to verify that the value of all parameters associated with the variables is positive, thus, as greater the index values, as higher the probability of an individual be a user of non-motorized and collective motorized (bus) transport mode.

The negative intercept on the model suggests there is a preference of the users for personal motorized (car/motorcycle) vehicles. Since value 1 was assigned to characteristics associated to non-motorized and collective motorized transport modes, the highest probability of using those transport modes is among individuals with the following characteristics: monthly family income below 3 minimum wages, living in rented domiciles, with educational background up to 
graduation, traveling for education purpose, making up to 3 daily trips, in average, which last longer than 15 minutes.

Based on the three highest estimated coefficients on the presented model in equation 2 , the explanatory variables average frequency of daily trips, monthly family income, and average time of travel are the ones which most influence or impact on the determination of the transport mode used by the analyzed users' groups. In this research, we can realize that the number of trips and the average time of travel are associated with the use of transport modes. With that in mind, one can infer that the trips made in non-motorized and collective motorized (bus) transport tend to demand more time, and for that reason, their users make a smaller number of daily trips.

Variables that determine the use of transport modes, based on the coefficient values, can be ordered according to the level of influence exerted in the following way: the purpose of the trip, housing characteristics, and user's educational background. People whose educational background is up to graduation and whose primary trip purpose relates to education tend to travel using non-motorized and collective motorized (bus) transport modes. One can understand that people with those characteristics are becoming financially stable, and for that reason, are not in a condition to own a vehicle, so they tend to use a more financially accessible transport mode. As for the type of housing, the survey revealed that most of the people who live in owned houses tend to travel using personal motorized (car/motorcycle) transport modes. That fact is in agreement with the common idea that motorized transport and owned house are a synonym of financial stability, which are seen as essential accomplishments for people's comfort.

Confirmation of some people's preference for personal motorized transport modes, based on the negative intercept value of the regression model presented in equation 2 , emphasizes the need for public policies that foster the permanence of non-motorized and collective motorized (bus) transport mode users, so that the increase of daily trips, the change of the main purpose of trip or the addition of daily activities, and the increase of the family income do not become the drivers of migration of these people to personal motorized transport modes.

As for the odds ratio presented in Table 4, we can conclude that people who travel, on average, three or more times a day have 4.72 times more chance of using non-motorized or collective motorized (bus) transport modes. Based on this research, the chances of a person to use those transport modes, according to the variables of the model presented on equation 2 , are given in the following ascending order: educational background (less or equal to graduation), housing characteristics (rented), purpose of trip (education), average time of travel (above 15 minutes), monthly family income (below 3 minimum wages), average frequency of daily trips (less or equal to 3 trips).

In short, one can conclude, based on the binary logistic regression, that the determination of transport mode choice is best explained by the variables average frequency of daily trips, monthly family income, the average time of travel, purpose of trip, housing characteristics, and educational background, in decreasing order of influence level.

\section{CONCLUSIONS}

Based on the results of this study, which aimed to understand the profile of transport users in Barreiras city, Bahia State, we confirm the hypothesis that statistical modeling of social, economic and urban population trip patterns variables, can determine the probability of 
individuals on using non-motorized and collective motorized (bus) transport modes. Besides that, it was possible to identify and quantify the effect of social, economic, and trip characteristics on the transport mode choice available in Barreiras.

The methodology applied in this research can assist the diagnostic of urban trips, which indeed contributes to the process of designing sustainable public policies to urban mobility. Once determining the logistic regression model simplifies the comprehension of cause and effect relationship between the characteristics as mentioned earlier and the transport mode choice, its usage promotes the prioritization of actions that help planning sustainable urban mobility.

Another critical aspect of the used methodological process is its potential application in Brazilian medium-sized cities, once the statistical analysis allows the determination of different statistic models according to the social, economic, and trip patterns characteristics concerning the non-motorized and motorized transport modes available in the places of its application.

\section{REFERENCES}

ABEP, Associação Brasileira de Empresas de Pesquisa (2016) Critério de classificação econômica Brasil. p. 1-6.

Arora, A. and G. Tiwari (2007) A Handbook for Socio-Economic Impact Assessment (SEIA) Methodology for Future Urban Transport (FUT) Projects. Transportation Research and Injury Prevention Program, Indian Institute of Technology. New Delhi. 99 p.

BRASIL. Constituição (1988) Constituição da República Federativa do Brasil. Brasília, DF: Senado Federal: Centro Gráfico. 292 p.

Cardoso, P. de B. and V. B. G. Campos (2016) Metodologia para planejamento de um sistema cicloviário. Transportes, v. 24, n. 4, p. 39-48. DOI:10.14295/transportes.v24i4.1158

Carse, A.; A. Goodman; R. L. Mackett; J. Panter and D. Ogilvie, (2013) The factors influencing car use in a cycle-frindly city: the case of Cambridge. Journal of Transport Geography, v. 28, p. 67-74. DOI: 10.1016/j.jtrangeo.2012.10.013

CNT, Confederação Nacional do Transporte (2017) Pesquisa Mobilidade da População Urbana 2017. Associação Nacional das Empresas de Transportes Urbanos. Brasília, Distrito Federal, Brasil.

Cohen J. (1992) A power primer. Psychol Bull. v. 112, n. 1, p. 155-159.

Contursi, C. M. B.; R. S. Oliveira; M. A. V. Silva and L. S. Portugal (2018) Análise da eficiência das regiões administrativas do Rio de Janeiro em função da mobilidade. Transportes, v. 26, n. 3, p. 103-119. DOI: 10.14295/transportes.v26i3.1627

Corrar, L. J.; E. Paulo and J. M. Dias Filho (2009) Análise Multivariada: para os cursos de administração, ciências contábeis e economia. 1. Edição. São Paulo: Atlas.

Coutinho, C. H. L.; F. J. C. Cunto and S. M. P. Ferreira (2015) Análise da severidade dos acidentes com motocicletas utilizando modelos probit e logit ordenados. Transportes, v. 23, n. 3, p. 60-66. DOI: 10.14295/transportes.v23i3.926

DENATRAN, Departamento Nacional de Trânsito (2018) Frota Municipal em Março 2018. Available at: <https://infraestrutura.gov.br/component/content/article/115-portal-denatran/8558-frota-de-veiculos-018.html> (accessed 5.5.2018).

Diez, J. M.; M. E. L. Lambas; H. Gonzalo; M. Rojo and A. G. Martinez (2018) Methodology for assessing the cost effectiveness of Sustainable Urban Mobility Plans (SUMPs). The case of the city of Burgos. Journal of Transport Geography, v. 68, p. 22-30. DOI: 10.1016/j.jtrangeo.2018.02.006

Ferrante, V. L. S. B.; V. Vertuan and B. E. C. Toledo (1997) Um modelo de análise socioeconômica: construção e resultados obtidos. Revista de Saúde Pública, v. 10, n. 2, p. 177-190. DOI: 10.1590/S0034-89101976000200005

Ferreira, J. C. and C. M. Patino (2015) O que realmente significa o valor-p? Jornal Brasileiro de Pneumologia, v. 41, n. 5, p. 485485. DOI: $10.1590 /$ S1806-37132015000000215

Gadepalli, R.; G. Tiwari and N. Bolia (2018) Role of user's sócio-economic and travel characteristics in mode choice between city bus and informal transit services: Lessons from household surveys in Visakhapatnam, India. Journal of Transport Geography, Article in press. DOI: 10.17632/7vzs2gtgbj.1\#file-297145a2-fb7c-4bb8-b1f8-21450db137be

Garcia, C. S. H. F.; M. D. R. M. R. Macário; E. D. D. A. G. Menezes and C. F. G. Loureiro (2018) Strategic Assessment of Lisbon's Accessibility and Mobility Problems from an Equity Perspective. Networks and Spatial Economics, v. 18, n. 2, p. $415-439$. DOI: $10.1007 / \mathrm{s} 11067-018-9391-4$

Gomide, A. A. (2006) Mobilidade Urbana, iniquidade e políticas sociais. Políticas sociais - acompanhamento e análise. IPEA. p. 242-250.

Horn, R. V. (1993) Statistical indicators for the economic and social sciences. Cambridge University Press. New York. USA. 50p.

IBGE, Instituto Brasileiro de Geografia e Estatística, (2018) Diretoria de Pesquisas, Coordenação de População e Indicadores Sociais, Estimativas da população residente com data de referência $1^{\circ}$ de julho de 2018. Available at: <https://cidades.ibge.gov.br/brasil/ba/barreiras/panorama> (accessed 30.5.2018). 
IBGE, Instituto Brasileiro de Geografia e Estatística (2010) Sinopse do Censo Demográfico de 2010. Available at: $<$ www.censo2010.ibge.gov.br/sinopse/index.php?dados=12\&uf=00> (accessed 13.1.2019).

IBGE, Instituto Brasileiro de Geografia e Estatística (2016) Pesquisa Nacional por Amostra de Domicílios. Síntese de Indicadores 2015. Coordenação de Trabalho e Rendimento. Rio de Janeiro. 108p.

Kaewkluengklom, R.; W. Satiennam; S. Jaensirisak and T. Satiennam (2017) Influence of psychological factors on mode choice behavior: Case study of BRT in KhonKaen City, Thailand. Transportation Research Procedia, v. 25, p. 5072-5082. DOI: 10.1016/j.trpro.2017.05.213

Lindner, A. and C. S. Pitombo (2016) Modelo logit binomial com componentes principais para estimação de preferência por modo de transporte motorizado. Journal of Transport Literature, v. 10, n. 3, p. 5-9. DOI: 10.1590/2238-1031.jtl.v10n3a1

López, O. S. and S. Montero (2018) Expert-citizens: Producing and contesting sustainable mobility policy in Mexican cities. Journal of Transport Geography, v. 67, p. 137-144. DOI: 10.1016/j.jtrangeo.2017.08.018

Machado, L. and L. S. Piccinini (2018) Os desafios para a efetividade da implantação dos planos de mobilidade urbana: uma revisão sistemática. Revista Brasileira de Gestão Urbana, v. 10, n.1, p. 72-94. DOI: 10.1590/2175-3369.010.001.A006

Mello, J. A. V. B.; A. J. R. Mello and R. D. Orrico Filho (2016) Centralidad basada en viaje y su reflexión sobre la estructura monopolicéntica de la Región Metropolitana de Río de Janeiro. Investigaciones Geográficas, Boletín del Instituto de Geografía, v. 2016, p. 74-89. DOI: 10.14350/rig.46184

Mingzhu, S.; M. Yin; X. Chen; L. Zhang and M. Li (2013) A simulation-based approach for sustainable transportation systems evolution end optimization: theory, systematic framework and applications. Social and Behavioral Sciences, v. 96, p. 22742286. DOI: 10.1016/j.sbspro.2013.08.257

Moons, E.; G. Wets and M. Aerts (2007) Nonlinear Models for determining Mode Choice. Progress in Artificial Intelligence. Lecture Notes in Computer Science, v. 4874, p. 183-194. DOI: 10.1007/978-3-540-77002-2_16

Páez, A. (2006) Exploring contextual variations in land use and transport analysis using a probit model with geographical weights. Journal of Transport Geography, v. 14, p. 167-176. DOI: 10.1016/j.jtrangeo.2005.11.002

Portugal, L. S. (2017) Transporte, Mobilidade e Desenvolvimento Urbano. Rio de Janeiro: Editora Elsevier. p. 360.

Rahula, T. M. and A. Vermab (2013) Study of Impact of Various Influencing Factors on NMT Mode Choice. Procedia Social and Behavioral Sciences, v. 104, p. 1112-1119. DOI: 10.1016/j.sbspro.2013.11.207

SEI, Superintendência de estudos Econômicos e Sociais da Bahia (2017) Cidades do Agronegócio no Oeste Baiano. Textos para Discussão. Secretária de Planejamento da Bahia. p. 1-40.

Shaw, C. and M. Russel (2017) Benchmarking cycling and walking in wix New Zealand Cities: Pilot Study 2015. Journal of Transport \& Health, v. 5, p. 56-57.

Silva, A. N. R.; M. A. N. Azevedo Filho; M. H. Macêdo; J. A. Sorratini; A. F. Silva; J. P. Lima and A. M. G. S. Pinheiro (2015) A comparative evaluation of mobility conditions in selected cities of the five Brazilian regions. Transport Policy, v. 37, p. 147156. DOI: $10.1016 / j . t r a n p o l .2014 .10 .017$

Stamm, C.; J. A. R. Staduto; J. F. and Y. M. Wadi (2013) A população urbana e a difusão das cidades de porte médio no Brasil. Interações, v. 14, n. 2, p. 251-265. DOI: 10.1590/S1518-70122013000200011

Triola, M. F. (2013) Introdução à Estatística. 11 edição. São Paulo: Livros técnicos e científicos.

Tyrinopoulos, Y. and C. Antoniou (2013) Factors affecting modal choice in urban mobility. European Transport Research Review, v. 5, p. 27-39. DOI: 10.1007/s12544-012-0088-3

Vale, D. S. (2013) Does commuting time tolerance impede sustainable urban mobility? Analyzing the impacts on commuting behavior as a result of workplace relocation to a mixed-use center in Lisbon. Journal of Transport Geography, v. 32, p. 3848. DOI: $10.1016 /$ j.jtrangeo.2013.08.003

Xu, Y.; A. Belyi; I. Bojic and C. Ratti (2018) Human mobility and socioeconomic status: Analysis of Singapore and Boston. Computers, Environment and Urban Systems. v. 72, p. 51-67. DOI: 10.1016/j.compenvurbsys.2018.04.001 